Available online at

http://jifnp.tp.ugm.ac.id
INDONESIAN FOOD AND NUTRITION PROGRESS

\title{
Growth of Lactobacillus paracasei SNP-2 in Peanut Milk and Its Survival in Fermented Peanut Milk Drink During Storage
}

\author{
Tyas Utami $^{\left.1^{*}\right)}$, Giyarto $^{2)}$, Titik F. Djaafar ${ }^{3)}$, Endang S. Rahayu ${ }^{1)}$ \\ ${ }^{1)}$ Department of Food and Agricultural Product Technology, Faculty of Agricultural Technology, \\ Universitas Gadjah Mada JI. Flora No 1, Bulaksumur, Yogyakarta, Indonesia 55281 \\ 2) Department of Agricultural Product Technology, Faculty of Agricultural Technology, Jember University, \\ Jl. Kalimantan 37, Tegalboto, Jember, Indonesia, 68121 \\ ${ }^{3)}$ Assessment Institute of Agricultural Technology, Jl. Rajawali 28, Demangan Baru, Yogyakarta, Indonesia 55228 \\ *) Corresponding author, e-mail address: tys_utami@yahoo.com.sg
}

Received 20 May 2014; Accepted 10 August 2014; Published Online 10 September 2014

\begin{abstract}
Fermentation of peanut milk added with various sucrose concentrations using candidate probiotic strain of Lactobacillus paracasei SNP-2 was investigated, and the lactic acid bacteria survival during storage of the fermented peanut milk drinks were also studied. Peanut milk fermentations were carried out at $37^{\circ} \mathrm{C}$ for $18 \mathrm{~h}$. It was found that peanut milk without addition of sucrose could support the growth of L. paracasei SNP-2, but not the production of lactic acid. Fermentation of peanut milk with addition of 2-10\% sucrose significantly increased the production of lactic acid. The numbers of lactic acid bacteria showed no marked reduction in the fermented peanut milk drinks during storage at $4{ }^{\circ} \mathrm{C}$ for 21 days, still sufficiently high to exert beneficial probiotic effects in the host. Fermented peanut milk drink using L. paracasei SNP-2 can be used as a non-dairy probiotic product.
\end{abstract}

Keywords: Lactic acid bacteria, viability, probiotic, fermented peanut milk

\section{Introduction}

Probiotic products have become an important choice for consumers, primarily due to the potential health benefits attributed to their consumption. The probiotic beneficial effects on human health are including inhibition of pathogenic microorganism, stimulation of immune system, cholesterol lowering effect, and prevention of gastrointestinal disorder (Hopzapel et al., 1998; Ouwehand and Salminen, 1998).

Lactic acid bacteria are the most important group of microorganisms used in the fermented milk and much of them are considered probiotics (Sieber and Dietz, 1998). With the growing interest of consumers in health-related food, the market for fermented products containing probiotic lactic acid bacteria would have a promising future. Dairy products have been used as vehicle for the probiotic bacteria and marketed in the form of fermented milks, however, there are consumer demand for nondairy-based probiotic products too (Prado et al., 2001) due to lactose intolerance, cholesterol content, and also demand for vegetarian probiotic products. The application of probiotic cultures in non-dairy products is a great challenge.

Peanut (Arachis hypogaea L.) is an important food crop with many health benefits. Peanuts were found to be a major source of edible oil and protein meal, and a good source of antioxidant, such as $p$-coumaric acid, that may be contributing factors to potential health benefits of their consumption (Talcot et al., 2005; Duncan et al., 2006). Peanut milk is the water extract of peanut that is an inexpensive source of protein and calories for human consumption. Just like, it is seen as a low-cost substitute for dairy milk for the developing countries. Being free of cholesterol, 
gluten and lactose, peanut milk is also a suitable food for lactose-intolerant consumers, vegetarians and milk-allergy patients. Like fermented soy products, peanut milk fermented with lactic acid bacteria may be suitable as a probiotic carrier to the host.

Several researchers have studied the fermentation of peanut milk by lactic acid bacteria (Beuchat and Nail, 1978; Bucker et al., 1979; Lee et al., 1991; Sunny-Roberts et al., 2004; and Isanga and Zhang, 2009). The growth of lactic acid bacteria in peanut milk depends on a number of factors, such as strain of lactic acid bacteria, availability of nutrition, and fermentation temperature and time. Lactobacillus paracasei SNP-2 which was previously identified as $L$. Acidophilus SNP-2 is found to be resistant to bile salt and low $\mathrm{pH}$, and could be used as probiotic agent (Purwandhani and Rahayu, 2004). Consumption of tape ketan (fermented glutinous rice) supplemented with $L$. acidophilus SNP-2 improved of fecal-volunteer's microbiota (Rahayu and Purwandhani, 2004). In this study, the effect of addition of various sugar concentrations on the growth of $L$. paracasei SNP-2 and acid production during peanut milk fermentation were tested. The survival of this microorganism on fermented peanut milk drink subsequent storage at refrigerated temperature $\left(4^{\circ} \mathrm{C}\right)$ was also evaluated.

\section{Materials and Methods Microorganism}

The starter culture of $L$. Paracasei SNP-2 which was previously identified as $L$. acidophilus SNP-2 was obtained from Food and Nutrition Culture Collection, Center for Food and Nutrition Studies, Universitas Gadjah Mada, Yogyakarta, Indonesia. The culture was stored in a mixture of $10 \%$ glycerol and $10 \%$ skimmed milk $(1: 1)$ at $-20^{\circ} \mathrm{C}$, and maintained by sub-culturing into sterilized MRS media and stored at $4^{\circ} \mathrm{C}$.

\section{Preparation of Peanut Milk}

The raw peanuts were purchased from a farmer in Bantul, Yogyakarta, Indonesia. Care was taken to ensure that good quality seeds were selected. Whole peanuts were first washed and soaked in water for seven hours at room temperature. After decanting the soaking water, the peanuts were ground and extracted with 20 times weight of water for $10 \mathrm{~min}$. The resultant slurry was filtered using centrifugal separator with a double-layered cheesecloth to obtain peanut milk. Peanut milk was then heated to $90^{\circ} \mathrm{C}$ for 15 min. The moisture, ash, fat, proteins, and carbohydrates contents in peanut milk were determined (AOAC, 1990).

\section{Fermentation of Peanut Milk and Storage}

Each of peanut milk added with various concentration of sucrose $(2-10 \% \mathrm{w} / \mathrm{v})$ was innoculated with $1 \%(\mathrm{v} / \mathrm{v})$ of $18 \mathrm{~h}$ of the single culture of $L$. paracasei SNP-2 in MRS broth. Fermented peanut milk without addition of sucrose served as the control. Peanut milk containing $L$. paracasei SNP-2 was incubated at $37^{\circ} \mathrm{C}$ for period of $18 \mathrm{~h}$. The population of the culture, $\mathrm{pH}$ and acid content were determined in the initial and end of fermentation periods.

The fermented peanut milk drinks were held at $4^{\circ} \mathrm{C}$ for 21 days. During storage period, the $\mathrm{pH}$, titratable acidity (expressed as \% lactic acid), and viable counts of lactic acid bacteria of the fermented peanut milk drinks were determined.

\section{Analytical Methods}

Proximate composition analisis were done on peanut milk. Moisture, ash, fat, and protein, were determined according AOAC method (AOAC, 1990). Titratable acidity was determined by titration with $0.1 \mathrm{~N} \mathrm{NaOH}$ solutions, and expressed as percent lactic acid (AOAC, 1990). The $\mathrm{pH}$ values of the samples were measured using $\mathrm{pH}$ meter (ToA/Jenway). MRS agar (Oxoid) with $1 \%$ $\mathrm{CaCO}_{3}$ was used for the enumeration of lactic acid bacteria. One milliliter of appropriate serial dilutions of each sample was pour-plated onto MRS agar media. After $48 \mathrm{~h}$ of incubation at $37^{\circ} \mathrm{C}$, the colonies with the clear zone that appeared on the plates were counted and calculated as $\mathrm{CFU} / \mathrm{ml}$.

\section{Statistical Analysis}

The mean values and the standard deviations were calculated from the data obtained with triplicate trials. Multiple comparisons of means were carried out by Duncan multiple range test. 


\section{Results and Discusion \\ Peanut Milk Fermentation}

The proximate composition of peanut milk is presented in Table 1 . The moisture content of peanut milk was $96.21 \%(w / w)$. The ash, fat, protein and carbohydrate (by different) contents in peanut milk are $0.09 \% ; 1.41 \%$; $1.48 \%$; and $0.81 \%$ respectively. In this study, the purpose of fermentation of peanut milk was to produce fermented peanut milk drink so that the total solids were quite low, not to be confused with peanut milk yogurt that have higher solid materials. Previous researchers reported much higher solid materials, protein content of peanut milk reported by Isanga and Zhang (2009) and Bucker et al., (1979) were $3.71 \%$ and $2.8 \%$ respectively. Other workers also reported lower moisture content of peanut milk i.e., $87.15 \%$ (Isanga and Zhang, 2009), and 90.6\% (Bucker et al., 1979). These differences were due to different water proportion on peanut milk preparation procedure, which were 1:20, while Isanga and Zhang (2009), and Bucker et al., (1979) used the peanut and water ratio of $1: 5$ and $1: 9$ respectively. In general, protein content of yoghurt is about 3.12\% (Tamime and Robinson, 1985), therefore protein content of yoghurt drink is approximately $1.6 \%$ which is close to $1.41 \%$ of protein content of peanut milk.

Table 2 shows the growth of $L$. paracasei SNP-2 in peanut milk with various concentration of added sucrose. The initial populations of lactic acid bacteria in peanut milk were adjusted to about $10^{7} \mathrm{CFU} / \mathrm{ml}$. After incubation at $37^{\circ} \mathrm{C}$ for 18 $\mathrm{h}$, the population of lactic acid bacteria reached the levels of $4.8 \times 10^{8} \mathrm{CFU} / \mathrm{ml}$ for peanut milk without addition of sucrose to $1.3 \times 10^{9} \mathrm{CFU} / \mathrm{ml}$ for peanut milk with addition of $10 \%$ sucrose. This result showed that Lactobacillus paracasei SNP-2 needs sucrose in the peanut milk, and its growth was more rapidly by the present of sucrose. Higher concentration of sucrose resulted in higher level of viable cell counts, however the differences in viable cell count of fermented peanut milk between no added sucrose and $10 \%$ added sucrose was less than 1 log cycles. It means that in the case of no added sucrose, L. paracasei SNP-2 can utilize carbohydrate in peanut milk for its growth. Sucrose was the major fermentable carbohydrate in the peanut milk (Bucker et al., 1979). Beuchat and Nail (1978) reported that the growth of $L$. acidophilus B-2092 was not significantly affected by the addition of $2 \%$ glucose, sucrose or lactose, however, $L$. acidophilus B-1910 was stimulated by glucose and lactose. Wang et al., (2003) reported that during $24 \mathrm{~h}$ of fermentation of soymilk by $L$. acidophilus CCRC 14079, sucrose, raffinose, and stachyose contents decreased, and fructose content increased. Capability of lactic acid bacteria to utilize sucrose, the main disaccharide in peanut milk and soymilk varied. Lactobacillus paracasei SNP-2 can utilize sucrose in the peanut milk, and its growth was affected by the present of sucrose.

Table 1. Proximate composition of peanut milk

\begin{tabular}{lc}
\hline \multicolumn{1}{c}{ Constituent } & $\begin{array}{c}\text { \% of constituent in } \\
\text { peanut milk }\end{array}$ \\
\hline Moisture & 96.21 \\
Ash & 0.09 \\
Protein & 1.41 \\
Fat & 1.48 \\
Carbohydrate (by different) & 0.81 \\
\hline
\end{tabular}

Table 2. The growth of Lactobacillus paracasei SNP-2 at $37^{\circ} \mathrm{C}$ in peanut milk with various concentration of sucrose

\begin{tabular}{ccc}
\hline \multirow{2}{*}{$\begin{array}{c}\text { Addition of sucrose } \\
\text { (\%) }\end{array}$} & \multicolumn{2}{c}{ Viable cell (cfu/ml) } \\
\cline { 2 - 3 } & \multicolumn{2}{c}{ Fermentation time (hours) } \\
\cline { 2 - 3 } & \multicolumn{1}{c}{0} & 18 \\
\hline 0 & $1.1 \times 10^{7}$ & $4.8 \times 10^{8}$ \\
2 & $1.1 \times 10^{7}$ & $6.0 \times 10^{8}$ \\
4 & $1.1 \times 10^{7}$ & $7.3 \times 10^{8}$ \\
6 & $1.2 \times 10^{7}$ & $7.9 \times 10^{8}$ \\
8 & $1.3 \times 10^{7}$ & $1.0 \times 10^{9}$ \\
10 & $1.4 \times 10^{7}$ & $1.3 \times 10^{9}$ \\
\hline
\end{tabular}

The initial $\mathrm{pH}$ and titratable acidity of peanut milk were about 6.4 and $0.03 \%$, respectively. Changes in $\mathrm{pH}$ and titratable acidity during fermentation of peanut milk inoculated with L. paracasei SNP-2 with various concentration of added sucrose are summarized in Table 3. In general titrarable acidity increased and the $\mathrm{pH}$ decreased after $18 \mathrm{~h}$ of fermentation. The lowest acid production was found in the fermented peanut milk without addition of sucrose which was seen that the titratable acidity increased from an initial level of $0.03 \%$ to only $0.14 \%$ after $18 \mathrm{~h}$, and the final $\mathrm{pH}$ was only 4.83 . This result indicated that although $L$. paracasei SNP-2 could grow in Peanut milk without added sucrose, but the titratable acidity was low. Sucrose at $0.60 \%(\mathrm{w} / \mathrm{v})$ was the major fermentable carbohydrate present in peanut milk (Bucker et al., 1979). Although the lactic acid bacteria can utilize sucrose in the peanut milk for 
their growth, however, the metabolism activity was very low indicated by the very low acid production. Addition of $2 \%$ sucrose significantly increased the acid production and reduced the $\mathrm{pH}$, but further addition of sucrose (4-10\%) resulted in relatively similar titratable acidity and $\mathrm{pH}$ of the fermented peanut milk. Thus addition of $2 \%$ of sucrose is sufficient for the cell growth and acid production during the $18 \mathrm{~h}$ lactic acid fermentation of peanut milk.

Table 3. $\mathrm{pH}$ and titratable acidity of peanut milk before and after fermentation at $37^{\circ} \mathrm{C}$ by L.paracasei SNP-2 with various concentration of sucrose

\begin{tabular}{|c|c|c|c|c|}
\hline \multirow{3}{*}{$\begin{array}{c}\text { Addition } \\
\text { of sucrose } \\
(\%)\end{array}$} & \multicolumn{4}{|c|}{ Fermentation time (hours) } \\
\hline & \multicolumn{2}{|c|}{0} & \multicolumn{2}{|c|}{18} \\
\hline & $\mathrm{pH}$ & $\begin{array}{l}\text { TA* } \\
\text { (\%) }\end{array}$ & $\mathrm{pH}$ & TA (\%) \\
\hline 0 & $6.27^{\mathrm{a}}$ & $0.03^{a}$ & $4.83^{\mathrm{a}}$ & $0.14^{\mathrm{a}}$ \\
\hline 2 & $6.29^{a}$ & $0.03^{a}$ & $4.03^{b}$ & $0.29^{b}$ \\
\hline 4 & $6.26^{\mathrm{a}}$ & $0.04^{\mathrm{a}}$ & $4.02^{b}$ & $0.29^{b}$ \\
\hline 6 & $6.38^{\mathrm{ab}}$ & $0.03^{a}$ & $4.00^{b}$ & $0.33^{b}$ \\
\hline 8 & $6.52^{b}$ & $0.03^{a}$ & $3.99^{b}$ & $0.34^{b}$ \\
\hline 10 & $6.45^{\mathrm{ab}}$ & $0.03^{\mathrm{a}}$ & $3.97^{b}$ & $0.33^{b}$ \\
\hline
\end{tabular}

*) Titratable acidity expressed as percent of lactic acid

${ }^{* *}$ ) Values in the same column with different superscripts are significantly different $(P<0.05)$

\section{Survival of Probiotic Bacteria on Fermented Peanut Milk Drink During Storage}

Lactobacillus paracasei SNP-2 attained high cell population of $4.8 \times 10^{8}-1.3 \times 10^{9} \mathrm{CFU} / \mathrm{ml}$ in peanut milk with various concentration of added sugar after $18 \mathrm{~h}$ of fermentation. During storage at $4^{\circ} \mathrm{C}$ for 21 days, there were no marked changes in the cell number of $L$. paracasei SNP-2 in fermented peanut milk drink with no addition of sugar and with addition of $2 \%$ sugar (Fig. 1). In contrast, the numbers of $L$. paracasei SNP-2 in fermented peanut milk drink with higher addition of sucrose (4-10\%) were decreased at the end of storage time. The viable cell counts of $L$. paracasei SNP-2 in the fermented peanut milk drink added with $8 \%$ sucrose decreased from 1.0 $\mathrm{x} 10^{9} \mathrm{CFU} / \mathrm{ml}$ on first day of storage to $6.2 \mathrm{x}$ $10^{8} \mathrm{CFU} / \mathrm{ml}$ on day 21 whereas that of in the fermented peanut milk drink added with $10 \%$ sucrose decreased from $1.3 \times 10^{9} \mathrm{CFU} / \mathrm{ml}$ on the first day of storage to $1.5 \times 10^{8} \mathrm{CFU} / \mathrm{ml}$ on day 21 .

Cell population of fermented peanut milk drinks were in the range of $4.8 \times 10^{8}-1.3 \times 10^{9}$ $\mathrm{CFU} / \mathrm{ml}$, which were sufficient amount for probiotic product. To exert their beneficial effects on the host, it is essential that lactic acid bacteria be alive in sufficient numbers in the products at the time of consumption. The number of probiotic bacteria in the food should be at least $10^{7} \mathrm{CFU}$ per $\mathrm{ml}$ or per $\mathrm{g}$ at the time of consumption in order to exert beneficial effects in the host (Ouwehand and Salminen, 1998). During storage at $4^{\circ} \mathrm{C}$ for 21 days, there were no marked changes in the cell number of $L$. paracasei SNP-2 in fermented peanut milk drink with no addition of sugar and with addition of $2 \%$ sugar, but there some decreases of cell population fermented peanut milk drink with higher addition of sucrose (4-10\%). Overall, all fermented peanut milk drink contained greater than $10^{7} \mathrm{CFU} / \mathrm{ml}$ of viable $L$. paracasei during 21 day storage at in yogurt $4^{\circ} \mathrm{C}$. Many studied showed low viability of probiotics in yogurt (Dave and Shah, 1977, and LourensHattingh and Viljoen, 2001). Our study found, however, that $L$. paracasei SNP-2 retained a satisfactory level of viable cells throughout the storage of fermented peanut milk drink. This is in agreement with study on lactic acid bacteria in fermented soymilk drinks (Wang et al., 2002). The numbers of $L$. acidophilus in fermented soymilk was relatively stable during 10 day storage at $5^{\circ} \mathrm{C}$, but they were much reduced during storage at $25^{\circ} \mathrm{C}$. The reduction of $L$. paracasei SNP- 2 counts in the fermented peanut milk drink, especially the ones supplemented with sucrose, may be related to the post-acidification of fermented peanut milk drink during storage.

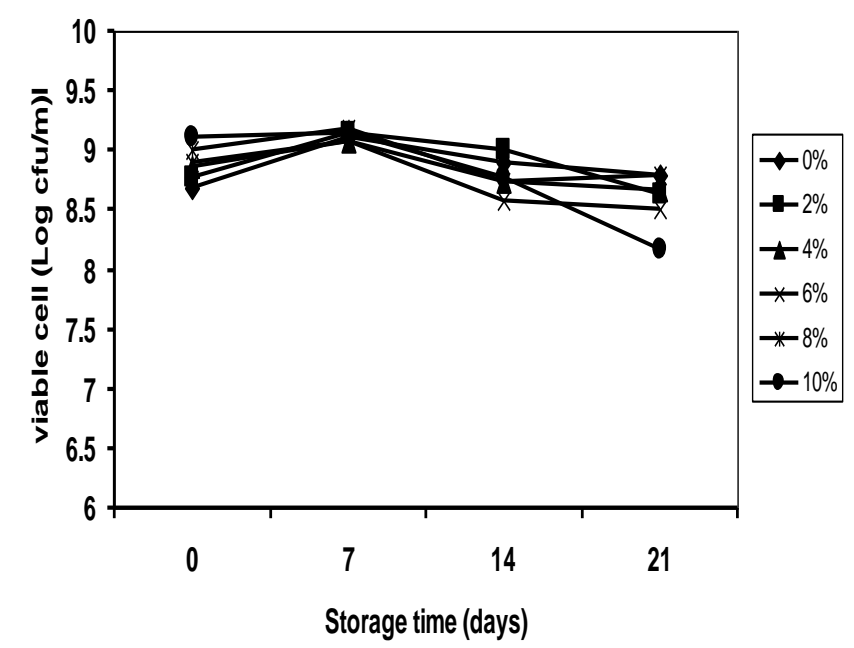

Fig. 1 Viability of Lactobacillus paracasei SNP-2 in fermented peanut milk drinkadded with various concentration of sucrose during storage at $4^{\circ} \mathrm{C}$ 


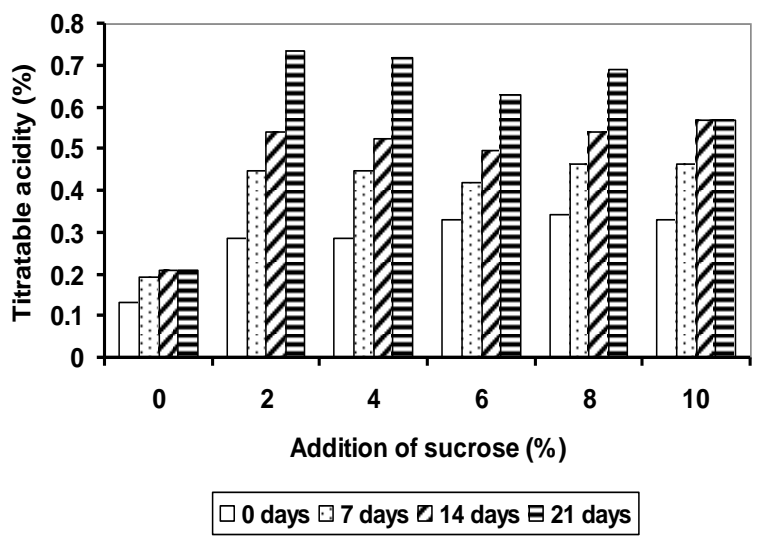

Fig. 2 Titratable acidity of fermented peanut milk drink with various concentration of sucrose during storage at $4^{\circ} \mathrm{C}$

The initial $\mathrm{pH}$ of fermented peanut milk drink without and with addition of sugar, were in the range of 4.83 to 3.97 and after 21 days storage at $4^{\circ} \mathrm{C}$, the $\mathrm{pH}$ were still in the range of 4.67 to 3.99. Thus, there were relatively no changes in the $\mathrm{pH}$ of fermented peanut milk drink during storage. In contrast the titratable acidities continued to increase during storage especially the ones with addition of sucrose (Fig. 2). After 21 day storage at $4^{\circ} \mathrm{C}$, the titratable acidities of fermented peanut milk drink with addition of sugar were in the ranges of 0.29 to $0.33 \%$. As comparison, the titratable acidity of fermented peanut milk drink without addition of sugar after 21 day storage at $4^{\circ} \mathrm{C}$ was only $0.14 \%$. According to Bucker et al., (1979), the acidity change rather than $\mathrm{pH}$ change was the more sensitive method to follow fermentation since the titratable acidity continued to increase after the $\mathrm{pH}$ no longer decline. This study showed that the correlation between post-storage acid production in fermented peanut milk drinks and the viability of L. paracasei SNP-2 is affected by the addition of sucrose. Wang et al., (2002) reported that the addition of sucrose to fermented soymilk drinks increased the rate of decline of the $\mathrm{pH}$ and the viable lactic acid bacteria during storage at $25^{\circ} \mathrm{C}$. Thus, further increase in acid production during cold storage may be attributed to greater metabolic activities of $L$. paracasei SNP- 2 at $4^{\circ} \mathrm{C}$ in the peanut milk with sucrose addition. Lactobacillus paracasei SNP-2 could grow to a high cell population in peanut milk and had a high viable count during the storage time $(8$ log $\mathrm{CFU} / \mathrm{ml}$ ), indicating that fermented peanut milk drink would be an excellent vehicle for probiotic.
Fermented peanut milk drink using L. paracasei SNP-2 can be used as a non-dairy probiotic product.

\section{Conclusion}

Lactobacillus paracasei SNP-2 showed good growth in peanut milk. The addition of $2 \%$ sucrose greatly enhanced the production of acid. Further increased in sucrose concentration did not significantly increased the acid production. During storage at $4{ }^{\circ} \mathrm{C}$ the acid productions were still continued especially for those with sucrose addition. After 21 day storage at $4^{\circ} \mathrm{C}$, all of the fermented peanut milk drinks retained in recommended levels of lactic acid bacteria. Lactobacillus paracasei SNP-2 could grow to a high cell population in peanut milk and had a high viable count during the storage time $(8$ log $\mathrm{CFU} / \mathrm{ml}$ ), indicating that fermented peanut milk drink suitable to be used as an excellent nondairy probiotic product.

\section{Acknowledgements}

Agriculture Research and Development Agency, Ministry of Agriculture, Indonesia through Research collaboration with University (2008) are acknowledged for financial support.

\section{References}

AOAC, 1990. Official Methods of Analysis, $18^{\text {th }}$ Edition. Association of Official Analytical Chemists, Washington, DC.

Beuchat, L.R. and Nail, B.J. 1978. Fermentation of peanut milk with Lactobacillus bulgaricus and L. acidophilus. J. Food Sci. 43: 11091112.

Bucker Jr, E.R., Mitchell Jr, J.H., and Johnson, M.G. 1979. Lactic fermentation of peanut milk. J. Food Sci. 44: 1534-1538.

Dave, R.I. and Shah, N.P. 1997. Viability of yogurt and probiotic bacteria in yogurts made from commercial starter cultures. Int. Dairy Sci. 79 (9): 1529-11536.

Duncan, C.E., Gorbet, D.W., Talcott, S.T. 2006. Phytochemical content and antioxidant capacity of water-soluble isolates from peanuts (Arachis hypogaea L.). Food Res. Int. 39: 898-904.

Hopzapel, W.H., Habere, P., Snel, J., Schillinger, U., and Huis in't Veld, J.H.J. 1998. Overview of gut flora and probiotics. Int. J. Food Microbiol. 41: 85-101. 
Isanga, J. and Zhang, G. 2009. Production and evaluation of some physical parameters of peanut milk yoghurt. LWT-Food Sci. Technol. 42: 1132-1138.

Lee, C. and Beuchat, L.R. 1991. Changes in chemical composition and sensory qualities of peanut milk fermented with lactic acid bacteria. Int. J. Food Microbiol. 13 (4): 273183.

Lourens-Hattingh, A. and Viljoen, B.C. 2001. Yogurt as probiotic carrier food. Review. Int. Dairy J. 11: 1-17.

Ouwehand, A.C. and Salminen, S. J. 1998. The Health Effects of Cultured Milk Products with Viable and Non-viable Bacteria. Int. Dairy J. 8: 749-758.

Prado, F.C., Parada, J.L., Pandey, A., and Zoclo, C.R. 2008. Trends in non-dairy probiotic beverages. Food Res. Int. 41: 111-123.

Purwandhani, S.N., and Rahayu, E.S. 2004. Isolation and selection of Lactobacillus potential for probiotic agent. Agritech. 23: 67-74.

Rahayu, E.S. and Purwandhani, S.N. 2004. Supplementation of Lactobacillus acidophilus SNP-2 on tape (fermented cassava) and its effect on human feces. Jurnal Teknologi dan Industri Pangan. 15: 129-134.

Sieber, R. and Dietz, U.T. 1998. Lactobacillus acidophilus and yogurt in the prevention and therapy of bacterial vaginosis. Int. Dairy J. 8: 599-607.

Sunny-Roberts, E.O., Otulona, E.T., and Iwakun, B.T. 2004. An evaluation of some quality parameters of a laboratory-prepared fermented groundnut milk. Eur. Food Res. Technol. 218: 452-455.

Tamime, A.Y. and Robinson, R.K. 1985. Yoghurt Science and Technology. Pergamon Press, Oxford, UK, $431 \mathrm{pp}$.

Talcot, S.T., Passeretti, S., Duncan, C.E., and Gorbet, D.W. 2005. Polyphenolic content and sensory properties of normal and high oleic acid peanuts. Food Chem. 90: 379388.

Wang, Y.C., Yu, R.C., and Chou, C.C. 2002. Growth and survival of bifidobacteria and lactic acid bacteria during the fermentation and storage of cultured soymilk drinks. Food Microbiol. 19: 501-508.
Wang, Y.C., Yu, R.C., Yang, H.Y., and Chou, C.C. 2003. Sugar and acid contents in soymilk fermented with lactic acid bacteria alone or simultaneously with bifidobacteria. Food Microbiol. 20: 333-338. 